of English he could remember was bread. He had had no chance to rejoin white society in the interim-hence "Buckley's Chance" for something that will never happen. (After Buckley left the expedition Collins went on to found Hobart as the land at the seaward end of Port Phillip Bay was inhospitable.)

Let me reassure Dr Vickers that despite our specialist registers, in Australia the control of specialist training has remained firmly in the hands of the various royal colleges. Their diplomas are awarded when training is completed, and the requirements for the FRACP, which is now to be the higher diploma of the Royal Australasian College of Physicians, make certain that this is training and not a cram course of the sort that used to be (and may still be so far as I know) necessary to have a chance of passing the FRCS in the 50s.

Despite the different forms of organisation of medical care in Australia and Britain, there is no hard evidence in the form of mortality rates that ours is worse than medical care in Britain. Specialist registers serve the purpose of delineating those who have done an approved training and obtained an approved standard of performance. That is their prime purpose. In many countries-and I gather that some Common Market countries fall in this category-the specialist register is used as a confirmation that a man (or woman) is worth a higher rate for the job.

To me, observing events from 12000 miles and three months by sea-mail away, the letters of Sir George Godber ${ }^{4}$ and $\mathrm{Mr} \mathrm{D}$ $\mathrm{H}$ Patey $^{\overline{5}}$ are extremely relevant to the discussion of the desirability of a specialist register. Apparently in the early years of the NHS the practising specialist in hospital could be referred to as a specialist or as a consultant. Mr Patey's memories of the use of the term "consultant" to cover the old "honorary staff" as a method of distinguishing their superior status from those who had always been paid by the hospital to provide essential specialist services are entirely in keeping with the natural human reaction to a threatened change of status. Most of the English-speaking world uses the term "specialist" for the man or woman still in active practice, while "consultant" is reserved as a reward for long service on retirement from the active hospital post. I wonder whether it could be that those doctors in Britain who are resisting the introduction of a specialist register feel that everyone is out of step except the British?

\author{
References \\ 1 Vickers, M D, British Medical fournal, 1976, 1, 328. \\ 2 British Medical fournal, 1976, 1, 343. \\ 3 Lancet, 1976, 1, 465, 525. \\ 4 British Medical fournal, 1976, 1, 227. \\ ${ }^{5}$ British Medical fournal, 1976, 1, 401.
}

\title{
Child health clinics and inverse care laws: evidence from longitudinal study of 1878 pre-school children
}

\author{
P M ZINKIN, C A COX
}

British Medical fournal, 1976, 2, 411-413

\section{Summary}

In a longitudinal study it was intended that 1878 children should receive periodic developmental examinations from the age of 6 weeks to 3 years. The children were divided into those with a high or low risk of developmental problems. Although clinic attendance rates of $85-89 \%$ were achieved in the catchment area $100 \%$ coverage was difficult because of population mobility and non-attendance at clinics. Children in families who moved away from the area were more difficult to trace and thus more likely to miss developmental examinations. This was a greater problem in the high-risk group. Altogether 683 home developmental examinations were carried out on 269 children who did not attend clinics. Thirty-five per cent of these children were in the highrisk group compared with $22 \%$ in the study population,

\footnotetext{
Wolfson Centre and Department of Developmental Paediatrics, Institute of Child Health, London WC1N 2AP

P M ZINKIN, MB, MRCP, senior lecturer

C A COX, MD, research fellow
}

and significantly more had developmental problems. Thus one possible way of reaching and helping such children is through home developmental examinations.

\section{Introduction}

The inverse care law as propounded by Tudor Hart ${ }^{1}$ states that "the availability of good medical care tends to vary inversely with the need for it in the population served"-that is, there tend to be more family doctors with fewer patients and more teaching hospitals and specialist services in those areas where there are more middle-class people than in poorer areas (usually industrial), where the morbidity is higher. Brimblecombe ${ }^{2}$ put the emphasis on use of services, and his law of inverse care states that "better-off families whose need is generally least make the optimal use of the services provided, while the poorer families whose need is commonly greatest make the least use of available resources." Both availability and use of medical resources are especially important for children, since they have the added disadvantage that they are totally dependent on others to recognise their health needs and to ensure that necessary care is obtained.

In a longitudinal study in the London Borough of Hounslow (known locally as the Hounslow Mother and Child Study), concerned with the early detection of delayed development, a small research team, working with the borough health department, 
wanted to ensure that all the babies in the study had periodic developmental examinations.

\section{Method}

The children-All babies born from October 1970 to February 1972 whose mothers lived within a geographical catchment area of Hounslow were included in the study. The area, in an outer London borough, was unremarkable in its degree of affluence or poverty. The social class distribution of the families (defined in terms of father's occupation $^{3}$ ) was similar to that in the National Child Development Study. ${ }^{4}$

The plan-Antenatal information collected at the time of attendance and perinatal and neonatal information was recorded on notes suitable for coding and data-processing by computer. Social information was obtained by a health visitor shortly after the child's birth. On the basis of this information the children were divided into those with a high or low risk of delayed and aberrant development, which might be associated with medical or educational handicap. The criteria chosen were those found to be the best predictors of such problems. ${ }^{4}$ These were, in order of importance: birth weight under $2500 \mathrm{~g}$ gestational age of 37 weeks or less, parity five or more, neonata illness, adverse delivery, and social class $\mathrm{V}$. We intended that all children should have developmental examinations at 6 weeks, and at $6,12,18,24$, and 36 months. At each examination age appointments were sent inviting clinic attendance. If second appointments were not kept, a health visitor assessed the situation, either encouraging the mother to attend the clinic or arranging for a project doctor to carry out the examination at home (with the agreement of the family doctor). The home examination was arranged irrespective of whether the child was in the high- or low-risk group. Every effort was made to ensure that children who moved from the catchment area had examinations at clinics near their new home.

\section{Results}

There were 1937 births during the study period. Perinatal mortality (21.7 per 1000), infant mortality (15.7 per 1000), and two later deaths left 1878 children for follow-up. Thirty mothers $(1 \cdot 6 \%)$ refused to participate, and a further 32 children $(1.7 \%)$ were lost to the study after the neonatal examination.

\section{POPULATION MOBILITY}

The number and frequency of moves related to whether the child was in the low-risk or high-risk group is shown in table I. Forty per cent of the children in the study had moved by the time they were 3 years old and $12 \%$ had moved more than once. High as these figures were, they underestimated the total number of moves since those within the catchment area itself were not included. Of the 751 families who moved $56(8 \%)$ moved back into the project area before the child was 3 years old. There was little difference between the percentage of children in the high-risk and low-risk groups who did not move or moved once, but the percentage of children in the high-risk group increased with the increasing number of moves.

Table II shows the main location of the families' new home with reference to the high- and low-risk groups. Only moves within the borough were more frequent in the high-risk group. It was harder to ensure that children who moved had all the developmental examinations, particularly in the first and most important year of life, and the

TABLE I-Frequency of moves related to risk group

\begin{tabular}{c|c|c|c|c|c}
\hline $\begin{array}{c}\text { No of } \\
\text { moves }\end{array}$ & $\begin{array}{c}\text { No in } \\
\text { total } \\
\text { study group }\end{array}$ & $\begin{array}{c}\% \text { Of } \\
\text { total } \\
\text { study group }\end{array}$ & $\begin{array}{c}\text { No in } \\
\text { low-risk } \\
\text { group }\end{array}$ & $\begin{array}{c}\text { No in } \\
\text { high-risk } \\
\text { group }\end{array}$ & $\begin{array}{c}\text { High-risk } \\
\text { group as \% } \\
\text { of total in } \\
\text { each removal } \\
\text { group }\end{array}$ \\
\hline $\begin{array}{c}\text { None } \\
1\end{array}$ & $\begin{array}{c}1127 \\
2\end{array}$ & 60 & 875 & 252 & 22 \\
3 & 166 & 28 & 419 & 99 & 19 \\
4 & 47 & 9 & 126 & 40 & 24 \\
\hline Total & 1878 & 100 & 1463 & 415 & 30 \\
\hline
\end{tabular}

Overall, $\chi^{2}=13.8 ; \mathrm{DF}=4 ; \mathrm{P}<0.01$
Linear trend for those who moved: $\chi^{2}=13.2 ; \mathrm{DF}=1 ; \mathrm{P}<0.001$
TABLE II-Location of moves related to risk group

\begin{tabular}{cc|c|c|c|c} 
Location & Total & $\begin{array}{c}\text { No in } \\
\text { low-risk } \\
\text { group }\end{array}$ & $\begin{array}{c}\text { No in } \\
\text { high-risk } \\
\text { group }\end{array}$ & $\begin{array}{c}\text { High-risk } \\
\text { group as \% } \\
\text { of total }\end{array}$ \\
\hline \begin{tabular}{ccc|c} 
Within borough \\
Great Britain
\end{tabular} & $\cdots$ & 139 & 97 & 42 & 30 \\
Abroad.. & $\cdots$ & 477 & 387 & 90 & 19 \\
\hline Total & & 751 & 588 & 163 & 23 \\
\hline
\end{tabular}

difficulties increased with the frequency of moves. Of those who moved away from the borough, $24 \%$ had a 6 -week examination, $44 \%$ had a 6-month examination, and the average percentage seen at 1 year and after was $68 \%$. Of children who moved within the borough $29 \%$ had a 6-week examination and $52 \%$ a 6 -month examination. The corresponding rates for those who did not move were $86 \%$ and $93 \%$.

\section{CLINIC ATTENDANCE WITHIN THE CATCHMENT AREA}

Table III shows that $85 \%$ to $96 \%$ of children living in the catchment area were examined at or near the recommended age. The clinic attendance was maintained after 1 year and the percentage of home examinations appeared to level off around $10 \%$.

TABLE III-Examinations within the catchment area

\begin{tabular}{|c|c|c|c|c|c|c|c|}
\hline \multirow[t]{2}{*}{ Examination } & \multirow{2}{*}{$\begin{array}{l}\text { No of } \\
\text { children } \\
\text { in area }\end{array}$} & \multicolumn{2}{|c|}{$\begin{array}{c}\text { Clinic } \\
\text { examinations }\end{array}$} & \multicolumn{2}{|c|}{$\begin{array}{c}\text { Home } \\
\text { examinations }\end{array}$} & \multicolumn{2}{|c|}{ Total seen } \\
\hline & & No & $0_{0}$ & No & 0 & No & $\%$ \\
\hline $\begin{array}{c}6 \text { weeks } \\
6 \text { months } \\
12 \text { months } \\
18 \text { months } \\
2 \text { years } \\
3 \text { years }\end{array}$ & $\begin{array}{l}1878 \\
1627 \\
1471 \\
1377 \\
1301 \\
1214\end{array}$ & $\begin{array}{r}1489 \\
1434 \\
1306 \\
1149 \\
1081 \\
995\end{array}$ & $\begin{array}{l}83 \\
88 \\
89 \\
83 \\
83 \\
82\end{array}$ & $\begin{array}{r}38 \\
67 \\
102 \\
128 \\
140 \\
133\end{array}$ & $\begin{array}{r}2 \\
4 \\
7 \\
9 \\
11 \\
11\end{array}$ & $\begin{array}{l}1527 \\
1501 \\
1408 \\
1277 \\
1221 \\
1128\end{array}$ & $\begin{array}{l}85 \\
92 \\
96 \\
93 \\
94 \\
93\end{array}$ \\
\hline
\end{tabular}

\section{HOME EXAMINATIONS}

A total of 269 families had 683 home visits, of which 608 were in the catchment area and 75 in other parts of the borough. Although $22 \%$ of the study children were in the high-risk group, 35\% (95) of the children who were examined at home were in this category. Interestingly, $70 \%$ of the children visited at home who were included in the high-risk group were there principally for medical reasons such as low birth weight and neonatal illness. High parity (five or more children) was the only frequent factor in those included solely for social reasons. The reasons for non-attendance at clinics have been reported elsewhere. ${ }^{5}$

A summary of the doctor's opinion at the home examination at two sample ages, 6 months and 2 years, is given in table IV. The term "suspect" was used to indicate that the examiner was not entirely satisfied with one or more aspects of the child's health or development. At 6 months not only were children in the high-risk group more likely to require a home examination, but $45 \%$ were suspect compared with $7 \%$ for the low-risk home examination group and $13 \%$ for the population as a whole at this age, clearly a statistically significant difference. At 2 years the same trend could be observed, though it was less pronounced than at 6 months.

The following case histories show the value of home developmental examinations.

TABLE IV-Relation between findings of home examinations at 6 months and 2 years and risk group

\begin{tabular}{c|c|c|c|c|c|c}
\hline & & 6 months* & & & 2 years $\dagger$ & \\
\cline { 2 - 6 } & Low risk & High risk & Total & Low risk & High risk & Total \\
\hline Normal & 26 & 21 & 47 & 96 & 46 & 142 \\
\hline Total & 2 & 17 & 19 & 8 & 17 & 25 \\
\hline Total & 28 & 38 & 66 & 104 & 63 & 167 \\
\hline
\end{tabular}

${ }^{*} \chi^{2}=9 \cdot 3 ; \mathrm{DF}=1 ; \mathrm{P}<0.01 . \quad+\chi^{2}=11.5 ; \mathrm{DF}=1 ; \mathrm{P}<0.001$ 
Case 1-A diabetic mother with a poor obstetric history gave birth to a much-wanted son, who was diagnosed as having Down's syndrome, at a hospital outside the area. Follow-up appointments sent by the hospital were not kept since the mother regarded the child as normal, having failed to understand the diagnosis. Indeed, she rarely kept her own hospital appointments. Although the paediatrician had requested health visitor follow-up, the mother had moved, changing her family doctor and health visitor, neither of whom was aware of the diagnosis. On home examination for failed clinic attendance the diagnosis and the condition became clear. Over subsequent home visits, discussion, gradual acceptance, and appropriate support became possible.

Case 2-A child born by caesarean section had numerous apnoeic attacks requiring intermittent positive pressure respiration and necessitating transfer to a specialised hospital. Paediatricians at both hospitals wanted to follow up the child. A comment in one set of hospital notes read "mother completely unreliable and continual history of failure to attend follow-up," though when she predictably failed to attend for follow-up another routine appointment was sent. When seen at home the mother had not kept appointments at either hospital. She was a motherly woman with seven children and a low income. She could not manage the journeys, but she welcomed the home paediatric examinations. Although early fears of severe handicap proved to be unfounded, the child showed signs of developmental delay at 3 years and nursery school placement was recommended.

Case 3-A child of a mother immobilised by rheumatoid arthritis gave concern from the first home examination at 6 weeks. By 6 months it was clear to the study doctor that the child had cerebral palsy and home physiotherapy was begun.

Case 4-Both twins of low birth weight, the first children of an educated mother, required special care during the neonatal period, transfer to a children's hospital being necessary for the second twin. The first twin was discharged with persisting feeding difficulties due to dietary intolerance, while the second twin remained in hospital. When the second twin was discharged the mother was expected to attend separate paediatric clinics for each twin, where diet, nutrition, and growth were supervised. Not surprisingly she could not take her babies for developmental examination, nor keep all the outpatient appointments. A home visit showed an exhausted, depressed mother with crying, "difficult" babies, both with some developmental delay. Although her family doctor and health visitor had visited her she welcomed the paediatric assessment and the advice on developmental and behavioural difficulties.

\section{Discussion}

There were two main reasons why children did not have periodic developmental examinations. The first was mobility of the population, which meant that even children who were traced successfully often missed at least one examination. The group of families who moved most often and who were thus most difficult to trace contained a high proportion of children in the high-risk group-whose need of the services was greatest.

The second reason was that, even within a borough with good child health services and a high level of resources, there were young children who would not have had necessary health and development checks within the existing structure of child health clinics and medical services. The parents' appreciation of the role of the clinics and of the possibilities of a positive approach to developmental examinations may be reflected in the high rate of clinic attendance, even though the interest engendered by a research study is not typical. Although some mothers were encouraged to attend clinics by health visitors, the need for this did not increase greatly after 1 year, nor did the usual decline in attendance occur. ${ }^{6}$ Nevertheless, even high clinic attendance rates are not grounds for complacency. More of the children who do not attend are those in greatest need. Thus the services should be brought to those children whose parents do not bring them to the services.

In Sweden and Finland, where infant mortality is the lowest in the world, $99^{\circ} \%$ of children are seen at clinics or on home visits by nurses specially trained in preventive paediatrics.? Where standards of living are uniformly high low infant mortality rates can be expected, but a careful study in Finland has shown that the better coverage provided by the preventive services is also part of the explanation. ${ }^{*}$

As early as 1958 Douglas $^{9}$ drew attention to the groups of children under 5 "that can only be reached by home visiting," yet in 1975 Mitchell" wrote "services are being used by those who need them least and are not reaching the most vulnerable families." While general practitioners are aware of these families' problems and needs, few can carry out periodic developmental examinations. Not only do most lack the necessary training in preventive and developmental paediatrics but they are also subjected to many other pressures, and "young children are in a very poor position to compete for the health care that they need with, for example, the acute illness of adults.";

Conclusions-Our results indicate that a larger proportion of children not brought to child health clinics, and thus not using available services, are in the group with a high risk of developmental problems than in the study population as a whole, a further example of the operation of the laws of inverse care. There is a need for awareness that families who move most often may contain a high proportion of high-risk children. One possible way of reaching and helping such children is through home developmental examinations.

\section{References}

${ }^{1}$ Hart, J T, Lancet, 1971, 1, 405.

2 Brimblecombe, F S W, in Bridging in Health, ed G McCachlan. London, Oxford University Press, 1975.

${ }^{3}$ Registrar General's Classification of Occupations. London, HMSO, 1966.

4 Davie, R, Butler, N, and Goldstein, H, From Birth to Seven. London, Longman, 1972.

${ }^{5}$ Zinkin, $\mathrm{P}$ M, and Cox, C A, in The Early Identification of Educationally "at Risk" Children, ed K Wedell and E C Raybould. Occasional publication No 6. School of Education, University of Birmingham, Educational Review, 1976

6 Ministry of Health, Report of the Sub-committee of the Central Health Services Council Medical Advisory Committee. London, HMSO, 1967.

7 Wynn, A, "Health Care Systems for Pre-School Children," paper read to Section of Paediatrics, Royal Society of Medicine, October 1975.

8 Wynn, M, and Wynn, A, The Protection of Maternity and Infancy: $A$ study of the Services for Pregnant Women and Young Children in Finland. London, Council of Children's Welfare, 1974.

9 Douglas, J W B, and Blomfield, J M, in Children under Five. London, George Allen and Unwin Ltd, 1958.

${ }^{10}$ Mitchell, R G, in Health Care of Mothers and Children in National Health Services: Implications for the United States, ed H M Wallace. Cambridge, Mass, Ballinger Publishing Company, 1975.

$A$ boy has an airgun pellet lodged inaccessibly in the back of the left orbit. The eye is undamaged. Is there any danger of lead leaking from the pellet causing toxicity?

There are several examples of human lead poisoning from lead shot lodged in various tissues of the body. There are even reports of a high incidence of death from lead poisoning among wild fowl with non-fatal lodgment of lead shot ${ }^{1}$ and in birds of prey feeding on such animals. ${ }^{2}$ So this boy is theoretically exposed but it depends on the position of the foreign body. It is unlikely that any great harm will ensue from lead poisoning but it might be reasonable to monitor the blood lead levels at three-monthly intervals over the next year or so.

\section{'Andrews, R, and Longcore, J R, Transactions of the 34th North American Wildlife and Natural Resources Conference, $\mathrm{p} 337$. Washington, 1969 \\ Benson, W W, Pharaoh, B, and Miller, P, Bulletin of Environmental Contamin- ation and Toxicology, 1974, 11, No 2.}

\section{Are antibiotics indicated in influenza?}

Antibiotics are not indicated for uncomplicated influenza as there is no evidence that they prevent the development of bacterial complications. Penicillin or ampicillin should not be given prophylactically as the dangerous bacterial pathogen in influenza is Staphylococcus aureus, which is usually resistant to benzylpenicillin and also to ampicillin. Should a patient with previously "healthy" lungs develop chest signs or frankly purulent sputum during an attack of influenza flucloxacillin should be prescribed in an adult dose of $500 \mathrm{mg}$ four times a day. If chest signs or purulent sputum develop in patients who have previously suffered from chronic bronchit/s they should be given either co-trimoxazole or ampicillin plus flucloxacillin. These agents will deal both with Haemophilus influenzae and Staph aureus. Patients with influenza who develop definite signs of pneumonia should probably be admitted to hospital. 